\title{
Benthic prey quantity and quality in the main mudflat feeding areas of the Tagus Estuary: Implications for bird and fish populations
}

\section{Cantidad y calidad de las presas bénticas en las principales zonas de alimentación de las planicies lodosas del estuario del Tajo: Implicaciones para las poblaciones de aves y peces}

\author{
I Cardoso $^{1 *}$, JP Granadeiro ${ }^{2}, \mathrm{H} \mathrm{Cabral}^{1}$ \\ ${ }^{1}$ Instituto de Oceanografia, Faculdade de Ciências da Universidade de Lisboa, Campo Grande, 1749-016 Lisboa, Portugal. \\ *E-mail: ipcardoso@fc.ul.pt \\ ${ }^{2}$ Centro de Biologia Ambiental, Faculdade de Ciências da Universidade de Lisboa, Campo Grande, 1749-016 Lisboa, Portugal.
}

\begin{abstract}
Estuaries are among the most productive environments in the coastal zone that may act as sink of pollutants. In this study we evaluated how levels of heavy metal contamination can be reflected in the macroinvertebrate communities of six Tagus Estuary mudflats, inferring their consequences to upper trophic levels. We used Shannon-Wiener's diversity, Pielou's evenness and Simpson's dominance indices, and macroinvertebrate densities to characterize benthic communities at the sites that presented different metal contamination loads. Those stations with high levels of contamination presented a lower diversity but also the highest prey density. This study indicated that unhealthy areas can still perform their ecosystem function with costs that remain to be evaluated. The biodiversity can be impoverished compared with other less contaminated sites, but with regard to their utilization as feeding areas by birds and fishes this is not a limiting factor. For this particular function of the mudflats, prey availability is the main characteristic determining the choice of one particular site as a bird and fish feeding area that may not be affected by heavy metal contamination.
\end{abstract}

Key words: contamination, heavy metals, macrobenthic community, mudflats, Tagus Estuary.

\section{Resumen}

Los estuarios son de los ambientes más productivos en la zona costera que pueden actuar como sumideros de contaminantes. En este estudio se evaluó cómo los niveles de contaminación por metales pesados pueden verse reflejados en las comunidades de macroinvertebrados de seis planicies lodosas del estuario del Tajo, infiriendo sus consecuencias en los niveles tróficos superiores. Se utilizaron los índices de diversidad de Shannon-Wiener, de igualdad de Pielou y de dominancia de Simpson, así como las densidades de macroinvertebrados para caracterizar las comunidades bentónicas en los sitios que presentaron diferentes cargas de contaminación por metales. Los sitios con altos niveles de contaminación presentaron una menor diversidad pero una mayor densidad de presas. Este estudio mostró que las zonas no saludables siguen desarrollando su función ecosistémica con costos aún por evaluar. La biodiversidad puede verse enpobrecida en comparación con otros sitios menos contaminados, sin embargo esto no es un factor limitante en cuanto a su utilización como área de alimentación para aves y peces. Para ello, la disponibilidad de presas es la característica principal que determina la selección de un sitio en particular como zona de alimentación para aves y peces, y puede no resultar afectada por la contaminación de metales pesados.

Palabras clave: comunidad macrobéntica, contaminación, estuario del Tajo, metales pesados, planicies lodosas.

\section{Introduction}

Estuaries and coastal wetlands are transition zones that link land, freshwater habitats and the sea. They provide essential ecological functions including shoreline protection, water quality improvement, and habitat and food for fishery resources, and other migratory and resident animals (Levin et al. 2001). Despite their ecological importance, estuaries have been a focus for industry and urbanization throughout history, as they provide excellent opportunities for transport, development, and natural dilution and dumping of wastes (Saiz-Salinas et al. 1996, Spencer 2002). In these ecosystems, sediments are an

\section{Introducción}

Los estuarios y humedales costeros son zonas de transición que unen hábitats terrestres, de agua dulce y marinos. Cumplen funciones ecológicas esenciales, incluyendo la protección de la línea de costa, el mejoramiento de la calidad del agua, y hábitat $\mathrm{y}$ alimento para recursos pesqueros y otros animales residentes y migratorios (Levin et al. 2001). A pesar de su importancia ecológica, los estuarios históricamente han sido sujetos a la industrialización y urbanización, ya que brindan excelentes oportunidades para el transporte, desarrollo, y descarga y dilución natural de desechos (Saiz-Salinas et al. 1996, Spencer 
important sink of a variety of pollutants, particularly heavy metals, and may also serve as an enriched source for benthic organisms (Wang et al. 2002), reason why they have traditionally been surveyed for environmental quality assessments (Saiz-Salinas et al. 1996).

Mudflats, widely common habitats in estuaries, are typically highly productive areas supporting a high biomass but relatively low species diversity. They provide both feeding and resting areas for important populations of waders and waterfowl, and also act as nursery areas for fish. Their main importance is the high productivity and consequent high biomass of prey items. In addition, they offer good quality resting areas due to their relative inaccessibility and distance from direct sources of disturbance (Evans et al. 1998). Therefore, it is important to assess their ecological quality in terms of both community structure and contaminant concentration.

For the species that use these areas as nursery or feeding grounds, the history of previous heavy metal exposure can be an important issue as it may affect subsequent metal uptake and bioaccumulation at different biological levels. Metal exposure may induce physiological and biochemical changes in cells receiving the input of trace metals as a result of induction of metal detoxification processes (Rainbow et al. 1990, 1999; Ansari et al. 2004). At the level of the whole organism and population, selection pressure may act on animals during ecotoxicologically significant metal exposure in their habitats, so it may be selectively advantageous that uptake be reduced (Rainbow et al. 1999). In addition, toxicants are also capable of influencing species distribution and abundance (Preston 2002).

The polychaete Nereis diversicolor (OF Müller 1776) and the bivalve Scrobicularia plana (da Costa 1778) are common species in most European estuaries. These invertebrates are particularly abundant in mudflat areas, where they are heavily consumed by both fish and birds in different periods of the tidal cycle (Bryan et al. 1985, Saiz-Salinas et al. 1996, Cabral 2000). The use of macroinvertebrates such as $N$. diversicolor and S. plana to assess the degree of heavy metal contamination in estuaries has been considered useful as it is recognized that they can be important links for contaminants between sediment and higher levels of the food chain (Bryan et al. 1985, SaizSalinas et al. 1996, Cheggour et al. 2005). Thus, trace metals are taken up by these organisms with the potential for accumulation in high body contents and concentrations (Bryan et al. 1985, Rainbow et al. 1990), which especially for non-essential metals depends mainly on their environmental levels (Amiard et al. 1987). The present study evaluates the quantity and quality of potential prey for fish and birds and their environment in terms of heavy metal contamination and community structure, in six mudflat areas of the Tagus Estuary, which has a substantial quantity of anthropogenic metals incorporated into its sediment (Caçador et al. 1993).
2002). En estos ecosistemas, los sedimentos son importantes sumideros de una gran variedad de contaminantes, particularmente de los metales pesados, y también pueden servir como una fuente enriquecida para los organismos bentónicos (Wang et al. 2002), por lo que también ha sido tradicionalmente estudiada su calidad ambiental (Saiz-Salinas et al. 1996).

Las planicies lodosas son hábitats estuarinos muy comunes y típicamente zonas muy productivas que sostienen una biomasa alta pero una relativamente baja diversidad de especies. Son áreas de alimentación y reposo para poblaciones importantes de aves vadeadoras y acuáticas y sirven como criaderos de peces. Su mayor importancia radica en su alta productividad y su consiguiente alta biomasa de presas. Además, constituyen áreas de reposo de buena calidad por su relativa inaccesibilidad y lejanía de fuentes directas de perturbación (Evans et al. 1998), por lo que resulta importante evaluar su calidad ecológica en cuanto a la estructura de la comunidad y la concentración de contaminantes.

Para las especies que usan estas áreas como criaderos o zonas de alimentación, la historia previa de exposición a metales pesados puede ser importante ya que puede afectar la futura captación y bioacumulación de metales a diferentes niveles biológicos. La exposición a metales puede inducir cambios fisiológicos y bioquímicos en las células afectadas por metales traza como resultado de los procesos de destoxificación (Rainbow et al. 1990, 1999; Ansari et al. 2004). Al nivel de todo el organismo o la población, la presión de selección puede actuar sobre los animales durante una exposición a metales ecotoxicológicamente signficativa en sus hábitats, por lo que puede resultar selectivamente ventajoso reducir la asimilación de estos elementos (Rainbow et al. 1999). Asimismo, las sustancias tóxicas son capaces de influenciar la distribución y abundancia de especies (Preston 2002).

El poliqueto Nereis diversicolor (OF Müller 1776) y el bivalvo Scrobicularia plana (da Costa 1778) son especies comunes en la mayoría de los estuarios europeos y particularmente abundantes en las planicies lodosas, donde son consumidas intensivamente tanto por peces como por aves durante los diferentes periodos del ciclo de mareas (Bryan et al. 1985, Saiz-Salinas et al. 1996, Cabral 2000). El uso de macroinvertebrados tales como $N$. diversicolor y S. plana para evaluar la contaminación por metales pesados en los estuarios ha resultado de gran utilidad ya que se reconoce que aquellos pueden ser importantes para vincular los contaminantes entre los sedimentos y los niveles superiores de la cadena trófica (Bryan et al. 1985, Saiz-Salinas et al. 1996, Cheggour et al. 2005). Los metales pesados son asimilados por estos animales que tienen el potencial de acumularlos en su organsimo en grandes cantidades y concentraciones (Bryan et al. 1985, Rainbow et al. 1990), lo cual especialmente para los metales no esenciales depende principalmente de sus niveles ambientales (Amiard et al. 1987). En el presente trabajo se evalúa la cantidad y calidad de presas potenciales para peces y aves, así como su ambiente, en cuanto a la contaminación por metales pesados y la estructura de la comunidad, en seis planicies lodosas del estuario del 


\section{Methods}

\section{Study area}

The Tagus Estuary $\left(38^{\circ} 40^{\prime} \mathrm{N}, 9^{\circ} 15^{\prime} \mathrm{W}\right)$ is one of the largest estuaries on the Atlantic coast of Europe, with a length of $50 \mathrm{~km}$ and an area of $325 \mathrm{~km}^{2}$, of which about $40 \%$ is intertidal. The mean river flow is $400 \mathrm{~m}^{3} \mathrm{~s}^{-1}$, being highly variable both seasonally and interannually. Salinity varies from zero $50 \mathrm{~km}$ upstream from the mouth to nearly 37 at the mouth of the estuary. Six mudflat areas were sampled: Arrentela, Rosário, São João da Talha, Sarilhos, Hortas, and Seca do Bacalhau (fig. 1).

\section{Sampling strategy}

In surveys carried out in July 2005, 10 sediment samples were collected at each mudflat, using a $12-\mathrm{cm}$ diameter corer down to a depth of $20 \mathrm{~cm}$. These samples were used to characterize community structure and to determine density estimates of the two invertebrate species considered for heavy metal determinations: the polychaete $N$. diversicolor and the bivalve S. plana. In the same period, extra samples were collected for sediment granulometry, organic matter, and heavy metal analyses. Also, individuals of $N$. diversicolor and S. plana were collected by hand to preserve their integrity and to ensure a minimum of 20 individuals per species per site for heavy metal determinations. These individuals were measured to ensure that similar size organisms were used in the analyses, kept in distilled water for $12 \mathrm{~h}$ depuration, weighed, and frozen until processing. Sediments for benthic community analysis were

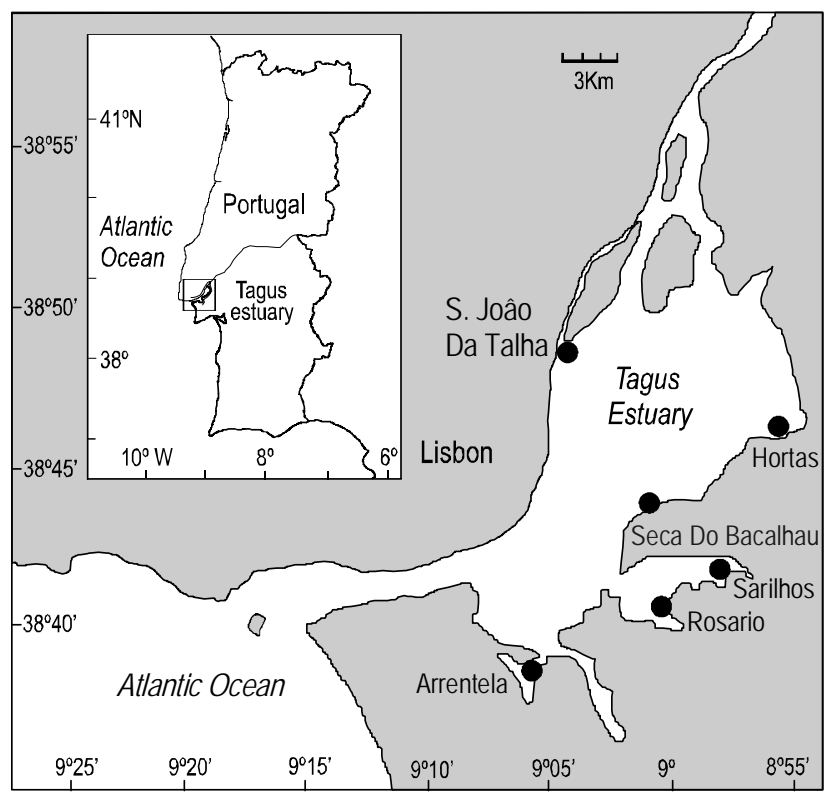

Figure 1. Location of the sampling sites in the Tagus Estuary. Figura 1. Localización de los sitios de muestreo en el estuario del Tajo.
Tajo cuyos contenidos de metales de origen antropogénico incorporados en los sedimentos son importantes (Caçador et al. 1993).

\section{Métodos}

\section{Área de estudio}

El estuario del Tajo $\left(38^{\circ} 40^{\prime} \mathrm{N}, 9^{\circ} 15^{\prime} \mathrm{W}\right)$ es uno de los más grandes de la costa atlántica de Europa, con una longitud de $50 \mathrm{~km}$ y un área de $325 \mathrm{~km}^{2}$, del cual alrededor de $40 \%$ es intermareal. El flujo fluvial principal es de $400 \mathrm{~m}^{3} \mathrm{~s}^{-1}$, y es muy variable tanto estacional como interanualmente. La salinidad varía desde cero unos $50 \mathrm{~km}$ río arriba de la boca hasta 37 en la boca del estuario. Se muestrearon seis planicies lodosas: Arrentela, Rosário, São João da Talha, Sarilhos, Hortas y Seca do Bacalhau (fig. 1).

\section{Estrategia de muestreo}

En julio de 2005 se recolectaron 10 muestras de sedimento de cada planicie lodosa, usando un nucleador de $12 \mathrm{~cm}$ de diámetro hasta una profundidad de $20 \mathrm{~cm}$. Estas muestras se utilizaron para caracterizar la estructura de la comunidad y para estimar la densidad de las dos especies de invertebrados consideradas para la determinación de metales pesados: el poliqueto $N$. diversicolor y el bivalvo S. plana. Durante el mismo periodo, se recolectaron muestras adicionales para analizar la granulometría, la materia orgánica y los metales pesados del sedimento. Asimismo, se recolectaron a mano individuos de $N$. diversicolor y S. plana para conservar su integridad y asegurar un mínimo de 20 individuos por especie por sitio para la determinación de metales pesados. Estos individuos se midieron para asegurar que se utilizaran organismos de tamaño similar en los análisis, y se mantuvieron en agua destilada durante $12 \mathrm{~h}$ para su depuración, se pesaron y se mantuvieron congelados hasta su procesamiento. Los sedimentos para el análisis de la comunidad béntica fueron transportados al laboratorio, tamizados a través de una malla de $0.5 \mathrm{~mm}$ y preservados en una solución de alcohol al $70 \%$. Todos los organismos fueron identificados y contados.

\section{Análisis granulométrico del sedimento}

Los sedimentos se secaron a $60^{\circ} \mathrm{C}$ hasta obtener peso constante. El contenido de materia orgánica en los sedimentos fue determinado mediante pérdida por combustión $(4 \mathrm{~h}$ a $500^{\circ} \mathrm{C}$ ). El análisis del tamaño de grano se realizó con una serie de tamices de diferente luz de malla, dividiendo los sedimentos en siete fracciones, de acuerdo con la escala de Wentworth: limo y arcilla $(<0.063 \mathrm{~mm})$, arena muy fina $(0.063-0.125 \mathrm{~mm})$, arena fina $(0.125-0.250 \mathrm{~mm})$, arena media $(0.250-0.500 \mathrm{~mm})$, arena gruesa $(0.500-1.000 \mathrm{~mm})$, arena muy gruesa $(1.000-2.000 \mathrm{~mm})$ y grava $(>2.000 \mathrm{~mm})$. Después de secarse, se pesó cada fracción retenida en cada tamiz, expresándo el resultado como porcentaje del peso total del sedimento. 
transported to the laboratory and sieved through a $0.5-\mathrm{mm}$ mesh and preserved in $70 \%$ alcohol solution. All the organisms were identified and counted.

\section{Granulometric analysis of sediments}

Sediments were dried at $60^{\circ} \mathrm{C}$ until constant weight was achieved. Organic matter content in sediments was determined by loss on ignition $\left(4 \mathrm{~h}\right.$ at $\left.500^{\circ} \mathrm{C}\right)$. Grain-size analysis was performed based on a series of sieves of different mesh size; sediments were divided into seven fractions, according to the Wentworth scale: silt and clay $(<0.063 \mathrm{~mm})$, very fine sand $(0.063-0.125 \mathrm{~mm})$, fine sand $(0.125-0.250 \mathrm{~mm})$, medium sand $(0.250-0.500 \mathrm{~mm})$, coarse sand $(0.500-1.000 \mathrm{~mm})$, very coarse sand $(1.000-2.000 \mathrm{~mm})$, and gravel $(>2.000 \mathrm{~mm})$. After being dried, each fraction retained in each sieve was weighed and expressed as percentage of the total sediment weight.

\section{Heavy metal analyses}

For heavy metal determinations, sediment samples were dried to constant weight at $80^{\circ} \mathrm{C}$. Subsamples of $0.1 \mathrm{~g}$ were digested with $2 \mathrm{~mL}$ of $\mathrm{HNO}_{3} / \mathrm{HCl}(3: 1 \mathrm{v} / \mathrm{v})$ (Otte 1991). The biological samples were depurated and dried to constant weight at $60^{\circ} \mathrm{C}$, and the percentage of water in the tissues was determined. Subsequently, $0.1 \mathrm{~g}$ of dry tissue were digested with $2 \mathrm{~mL}$ of a mixture of nitric and perchloric acid (suprapure quality, 9:1), as described by Julshamn et al. (1982).

The concentrations of $\mathrm{Pb}, \mathrm{Zn}, \mathrm{Cu}$, and $\mathrm{Cd}$ were determined, both in sediments and in $N$. diversicolor and S. plana samples, using a GBC 932 Plus atomic absorption spectrometer with a GBC GF3000 graphite oven. The limits of detection for $\mathrm{Pb}$, $\mathrm{Zn}, \mathrm{Cu}$, and $\mathrm{Cd}$ were $2.5,0.05,0.5$, and $0.25 \mu \mathrm{g} \mathrm{L}^{-1}$, respectively. For sediment samples, standard additions and sludge reference materials were used (EC standard CRM 145 and $146)$, and all precision errors were inferior to $2 \%$. For biological samples, calibration curves were used for the determination of $\mathrm{Cu}$ and $\mathrm{Zn}$, whereas standard addition procedures were employed for the determination of $\mathrm{Cd}$ and $\mathrm{Pb}$. Procedural blanks were run for all samples.

\section{Data analyses}

The Simpson dominance, Shannon-Wiener diversity, and Pielou evenness indices (Ludwig and Reynolds 1988, Krebs 1989) were calculated to evaluate the structure of macroinvertebrate communities in the six mudflat areas.

To evaluate differences in heavy metal concentrations between sites and organisms, ANOVAs were performed (São João da Talha was excluded from this analysis since sufficient individuals of $S$. plana were not obtained in the sampling surveys at this site). For each species and heavy metal, an ANOVA was also used to assess differences among sampling areas. Whenever the null hypothesis was rejected, a posteriori Tukey tests were performed. Linear regression models were

\section{Análisis de los metales pesados}

Para las determinaciones de los metales pesados, se secaron las muestras de sedimento hasta peso constante a $80^{\circ} \mathrm{C}$. Se digirieron submuestras de $0.1 \mathrm{~g}$ con $2 \mathrm{~mL}$ de $\mathrm{HNO}_{3} / \mathrm{HCl}(3: 1 \mathrm{v} / \mathrm{v})$ (Otte 1991). Las muestras biológicas fueron depuradas y secadas hasta peso constante a $60^{\circ} \mathrm{C}$, y se determinó el porcentaje de agua en los tejidos. Subsecuentemente, se digirió $0.1 \mathrm{~g}$ de tejido seco con $2 \mathrm{~mL}$ de una mezcla de ácidos nítrico y perclórico (calidad suprapur, 9:1), según lo descrito por Julshamn et al. (1982).

$\mathrm{Se}$ determinaron las concentraciones de $\mathrm{Pb}, \mathrm{Zn}, \mathrm{Cu}$ y $\mathrm{Cd}$, tanto en los sedimentos como en las muestras de $N$. diversicolor y S. plana, usando un espectrómetro de absorción atómica GBC 932 Plus con un horno de grafito GBC GF3000. Los límites de detección para $\mathrm{Pb}, \mathrm{Zn}, \mathrm{Cu}$ y $\mathrm{Cd}$ fueron 2.5, 0.05, 0.5 y $0.25 \mu \mathrm{g} \mathrm{L}^{-1}$, respectivamente. Para las muestras de sedimento se utilizaron adiciones estándar y materiales de referencia certificados (CRM 145 y 146), y todos los errores de precisión fueron menores que $2 \%$. Para las muestras biológicas se usaron curvas de calibración para la determinación de $\mathrm{Cu}$ y $\mathrm{Zn}$, mientras que para la determinación de $\mathrm{Cd}$ y $\mathrm{Pb}$ se usó el procedimiento de adiciones estándar. Se procesaron blancos para todas las muestras.

\section{Análisis de datos}

Se calcularon los índices de dominancia de Simpson, de diversidad de Shannon-Wiener y de igualdad de Pielou (Ludwig y Reynolds 1988, Krebs 1989) para evaluar la estructura de las comunidades de macroinvertebrados en las seis planicies lodosas.

Se realizó un análisis de varianza (ANOVA) para evaluar las diferencias en las concentraciones de metales pesados entre los sitios y los organismos (São João da Talha fue excluido de este análisis ya que allí no se obtuvieron suficientes individuos de S. plana durante los muestreos). Para cada especie y metal pesado también se usó un ANOVA para determinar las diferencies entre los sitios de muestreo. En los casos en que se rechazó la hipótesis nula se realizaron pruebas a posteriori de Tukey. También se utilizaron modelos de regresión lineal para evaluar las relaciones entre los niveles de contaminación de los sedimentos y de $N$. diversicolor y $S$. plana. Todos los análisis se llevaron a cabo con la paquetería Statistica 6.0, considerando un nivel de confianza de 0.05 en todos los procedimientos. Para evaluar la eficiencia de la bioacumulación de metales se calculó el factor de acumulación biota-sedimento (BSAF), el cual se define como la razón entre la concentración de metales en un organismo y en el sedimento (Szefer et al. 1999, Usero et al. 2005). Para determinar los patrones principales de los niveles de contaminación en los seis sitios considerados y los índices de diversidad de la comunidad, se realizó un análisis de correspondencia canónica (CCA), usando Canoco para Windows 4.5. 
also used to evaluate the relationships between sediment and $N$. diversicolor and S. plana contamination levels. All these analyses were performed using Statistica 6.0 software and a 0.05 confidence level was considered in all test procedures. To evaluate the efficiency of metal bioaccumulation, the biosediment accumulation factor (BSAF) was calculated, which is defined as the ratio between the metal concentration in the organism and in the sediment (Szefer et al. 1999, Usero et al. 2005). To outline the main patterns of the contamination levels of the six areas considered and community diversity indices a canonical correspondence analysis (CCA) was performed, using Canoco for Windows 4.5.

\section{Results}

\section{Macroinvertebrate communities}

Diversity and evenness were quite low in all the sampling areas (table 1). The maximum number of taxa (11) was registered at Seca do Bacalhau, while the lowest values corresponded to the São João da Talha and Rosário mudflats (4 and 6 taxa, respectively) (table 2).

Macroinvertebrate assemblages were dominated by few species, especially by $N$. diversicolor, with densities between 20 ind $\mathrm{m}^{-2}$ in Seca do Bacalhau and 485 ind $\mathrm{m}^{-2}$ in Rosário, and by Hydrobia ulvae (Pennant 1777), with densities of 210 and 2830 ind $\mathrm{m}^{-2}$ in Seca do Bacalhau and Rosário, respectively. Scrobicularia plana was also a common species at most sites,

\section{Resultados}

\section{Comunidades de macroinvertebrados}

La diversidad e igualdad fueron bastante bajas en todas las zonas de muestreo (tabla 1). Se registró el mayor número de taxones (11) en Seca do Bacalhau, y los menores en São João da Talha y Rosário (4 y 6 , respectivamente) (tabla 2).

Las comunidades de macroinvertebrados estuvieron dominadas por pocas especies, y en especial por $N$. diversicolor, con densidades entre 20 ind $\mathrm{m}^{-2}$ en Seca do Bacalhau y 485 ind $\mathrm{m}^{-2}$ en Rosário, y por Hydrobia ulvae (Pennant 1777), con densidades entre 210 y 2830 ind $\mathrm{m}^{-2}$ en Seca do Bacalhau y Rosário, respectivamente. Scrobicularia plana también resultó ser una especie común en la mayoría de los sitios, con densidades

Table 1. Diversity index values for the six mudflats sampled.

Tabla 1. Valores de los índices de diversidad para las seis planicies lodosas muestreadas.

\begin{tabular}{lccc}
\hline Mudflat & $\mathrm{H}^{\prime}$ & Simpson index & $\mathrm{J}^{\prime}$ \\
\hline Arrentela & 1.708 & 0.418 & 0.229 \\
São João da Talha & 1.571 & 0.386 & 0.240 \\
Hortas & 1.970 & 0.323 & 0.252 \\
Rosário & 1.518 & 0.483 & 0.156 \\
Seca do Bacalhau & 2.549 & 0.245 & 0.385 \\
Sarilhos & 1.852 & 0.377 & 0.202 \\
\hline
\end{tabular}

Table 2. Mean densities (ind $\mathrm{m}^{-2}$ ) of the taxa found at the mudflats surveyed.

Tabla 2. Densidades medias (ind $\mathrm{m}^{-2}$ ) de los taxones encontrados en las planicies lodosas estudiadas.

\begin{tabular}{|c|c|c|c|c|c|c|c|}
\hline Taxa & & Arrentela & Seca do Bacalhau & Hortas & Rosário & Sarilhos & São João da Talha \\
\hline \multirow[t]{4}{*}{ Polychaete } & Nereis diversicolor & 160 & 20 & 90 & 485 & 260 & 177.8 \\
\hline & Nephthys sp. & & 5 & & & & \\
\hline & Tharyx sp. & 25 & 55 & & 20 & & \\
\hline & Capitela capitata & 15 & 15 & & & & \\
\hline Olygochaete & Oligochaete & & 55 & 515 & & 115 & \\
\hline \multirow[t]{2}{*}{ Gastropoda } & Hydrobia ulvae & 655 & 210 & 370 & 2830 & 1640 & 240 \\
\hline & Hydrobia ventrosa & 5 & & & & 5 & \\
\hline Bivalvia & Scrobicularia plana & 194.4 & 25 & 75 & 590 & 265 & 25 \\
\hline \multirow[t]{6}{*}{ Crustacea } & Palaemon elegans & & 85 & & 205 & 588.9 & \\
\hline & Cyathura carinata & 27.8 & 10 & 65 & & 20 & \\
\hline & Carcinus maenas & & & & & 10 & \\
\hline & Isopoda n.i. & 5 & 5 & & & & \\
\hline & Amphipoda n.i. & & 5 & & & & \\
\hline & Ostracoda & & & 10 & 100 & & \\
\hline Insecta & & & & 15 & & 5 & 45 \\
\hline
\end{tabular}


with densities ranging from 25 ind $\mathrm{m}^{-2}$ in Seca do Bacalhau to 194 ind $\mathrm{m}^{-2}$ in Arrentela. The crustacean Cyathura carinata (Krøyer 1847) was found at Seca do Bacalhau, Sarilhos, Hortas, and Arrentela but with low densities of 10, 20, 65, and 27.8 ind $\mathrm{m}^{-2}$, respectively (table 2). Sarilhos and Rosário were the mudflats with more prey availability, showing maximium values of $N$. diversicolor and S. plana densities (table 2).

\section{Sediment characteristics and contamination}

Sediments presented a high silt and clay content $(>80 \%)$ at all sampling sites except for Seca do Bacalhau, where they were composed of $40 \%$ sand and $60 \%$ silt and clay. The organic matter content was highest in Hortas and São João da Talha (16\%) and lowest in Seca do Bacalhau (7\%).

For all the heavy metals analyzed, significant differences between mudflats were obtained ( $\mathrm{F}>4.9, \mathrm{P}<0.05)$. For $\mathrm{Pb}$ and $\mathrm{Zn}$, maximum contamination was observed at Rosário, where we obtained values of $46.94 \mu \mathrm{g} \mathrm{g}^{-1}$ and $389.2 \mu \mathrm{g} \mathrm{g}^{-1}$, respectively. A similar range of contamination was observed at Sarilhos, where Cd contents were the highest, with $0.35 \mu \mathrm{g} \mathrm{g}^{-1}$. For $\mathrm{Cu}$, the highest concentration $\left(20.17 \mu \mathrm{g} \mathrm{g}^{-1}\right)$ was recorded at São João da Talha. For almost all analyzed metals, Seca do Bacalhau was the less contaminated mudflat, with $\mathrm{Cu}, \mathrm{Cd}$, and $\mathrm{Pb}$ contents of $7.32,0$, and $10.59 \mu \mathrm{g} \mathrm{g}^{-1}$, respectively. Therefore, the most contaminated areas were Rosário and Sarilhos (fig. 2).

\section{Contamination of N. diversicolor and S. plana}

Significant differences for all metals analyzed were found between sampling sites $(F>3.7, P<0.05)$ and species $(F>$ $59.7, P<0.05)$, except for $\mathrm{Cu}$, for which no differences between species were found $(F>1.7, P>0.05)$. For each species, the differences in heavy metal concentrations between mudflats were also significant. For $N$. diversicolor, the highest concentrations of $\mathrm{Cu}$ were found at Sarilhos and Seca do Bacalhau (11.35 and $9.21 \mu \mathrm{g} \mathrm{g}^{-1}$, respectively), and the highest $\mathrm{Zn}$ and $\mathrm{Pb}$ values were recorded at Sarilhos (143.07 and $6.06 \mu \mathrm{g} \mathrm{g}^{-1}$, respectively), while $\mathrm{Cd}$ was only detected in individuals collected at Sarilhos (fig. 3). Differences between mudflats were also significant for S. plana. The individuals collected at Rosário were the most contaminated, with $\mathrm{Cd}, \mathrm{Pb}$, and $\mathrm{Zn}$ contents of $0.31,16.70$, and $831.42 \mu \mathrm{g} \mathrm{g}^{-1}$, respectively, though the highest $\mathrm{Cu}$ values were recorded at Seca do Bacalhau (fig. 4).

For all the metals analyzed, S. plana had higher BSAF values than $N$. diversicolor, with a maximum for $\mathrm{Zn}$ (4.5734). For $N$. diversicolor, the highest BSAF values corresponded to $\mathrm{Cu}$ (1.2584) and $\mathrm{Zn}$ (1.1100) (table 3).

The relationships between heavy metals in sediment and in $N$. diversicolor and S. plana individuals were not significant, except for $\mathrm{Pb}$ in $N$. diversicolor, for which the linear regression desde 25 ind $\mathrm{m}^{-2}$ en Seca do Bacalhau hasta 194 ind $\mathrm{m}^{-2}$ en Arrentela. El crustáceo Cyathura carinata (Krøyer 1847) se encontró en Seca do Bacalhau, Sarilhos, Hortas y Arrentela, pero con densidades bajas de 10, 20, 65 y 27.8 ind $\mathrm{m}^{-2}$, respectivamente (tabla 2). Sarilhos y Rosário resultaron ser las planicies lodosas con mayor disponibilidad de presas, con densidades máximas de N. diversicolor y S. plana (tabla 2).

\section{Carácteristicas del sedimento y contaminación}

Los sedimentos presentaron un alto contenido de limo y arcilla ( $>80 \%)$ en todos los sitios de muestreo excepto en Seca do Bacalhau, donde estuvieron compuestos por $40 \%$ de arena y $60 \%$ de limo y arcilla. El contenido de materia orgánica fue mayor en Hortas y São João da Talha (16\%) y menor en Seca do Bacalhau (7\%).

Para todos los metales pesados analizados se obtuvieron diferencias significativas entre las planicies lodosas $(F>4.9$, $P<0.05)$. La máxima contaminación por $\mathrm{Pb}$ y $\mathrm{Zn}$ se registró en Rosário, donde se obtuvieron valores de $46.94 \mu \mathrm{g} \mathrm{g}^{-1} \mathrm{y}$ $389.2 \mu \mathrm{g} \mathrm{g}^{-1}$, respectivamente. Se observó un intervalo de contaminación similar en Sarilhos, donde los contenidos de $\mathrm{Cd}$ fueron los más altos, con $0.35 \mu \mathrm{g} \mathrm{g}^{-1}$. La mayor concentración de $\mathrm{Cu}\left(20.17 \mu \mathrm{g} \mathrm{g}^{-1}\right)$ se registró en São João da Talha. En cuanto a casi todos los metales analizados, Seca do Bacalhau resultó ser el sitio menos contaminado, con contenidos de $\mathrm{Cu}$, $\mathrm{Cd}$ y $\mathrm{Pb}$ de $7.32,0$ y $10.59 \mu \mathrm{g} \mathrm{g}^{-1}$, respectivamente. Por tanto, los sitios más contaminados fueron Rosário y Sarilhos (fig. 2).

\section{Contaminación de N. diversicolor y S. plana}

Para todos los metales analizados se encontraron diferencias significativas entre los sitios de muestreo $(F>3.7, P<$ $0.05)$ y las especies $(F>59.7, P<0.05)$, excepto en el caso del $\mathrm{Cu}$, para el cual no se registraron diferencias entre las especies $(F>1.7, P>0.05)$. Para cada especie las diferencias en las concentraciones de metales pesados entre los sitios también fueron significativas. Para N. diversicolor, las mayores concentraciones de $\mathrm{Cu}$ se encontraron en Sarilhos y Seca do Bacalhau (11.35 y $9.21 \mu \mathrm{g} \mathrm{g}^{-1}$, respectivamente), y los valores más altos de $\mathrm{Zn}$ y $\mathrm{Pb}$ se registraron en Sarilhos (143.07 y $6.06 \mu \mathrm{g} \mathrm{g}^{-1}$, respectivamente), mientras que sólo se detectó Cd en los individuos recolectados en Sarilhos (fig. 3). Las diferencias entre los sitios de muestreo también resultaron significativas para $S$. plana. Los individuos recolectados en Rosário fueron los más contaminados, con contenidos de $\mathrm{Cd}, \mathrm{Pb}$ y $\mathrm{Zn}$ de $0.31,16.70$ y $831.42 \mu \mathrm{g} \mathrm{g}^{-1}$, respectivamente, aunque los mayores valores de $\mathrm{Cu}$ fueron registrados en Seca do Bacalhau (fig. 4).

Para todos los metales analizados $S$. plana presentó mayores valores de BSAF que $N$. diversicolor, con un máximo para el Zn (4.5734). Para $N$. diversicolor los mayores valores de BSAF correspondieron al $\mathrm{Cu}(1.2584)$ y al $\mathrm{Zn}$ (1.1100) (tabla 3).

Las relaciones entre los metales pesados en los sedimentos y en los individuos de $N$. diversicolor y $S$. plana no fueron 

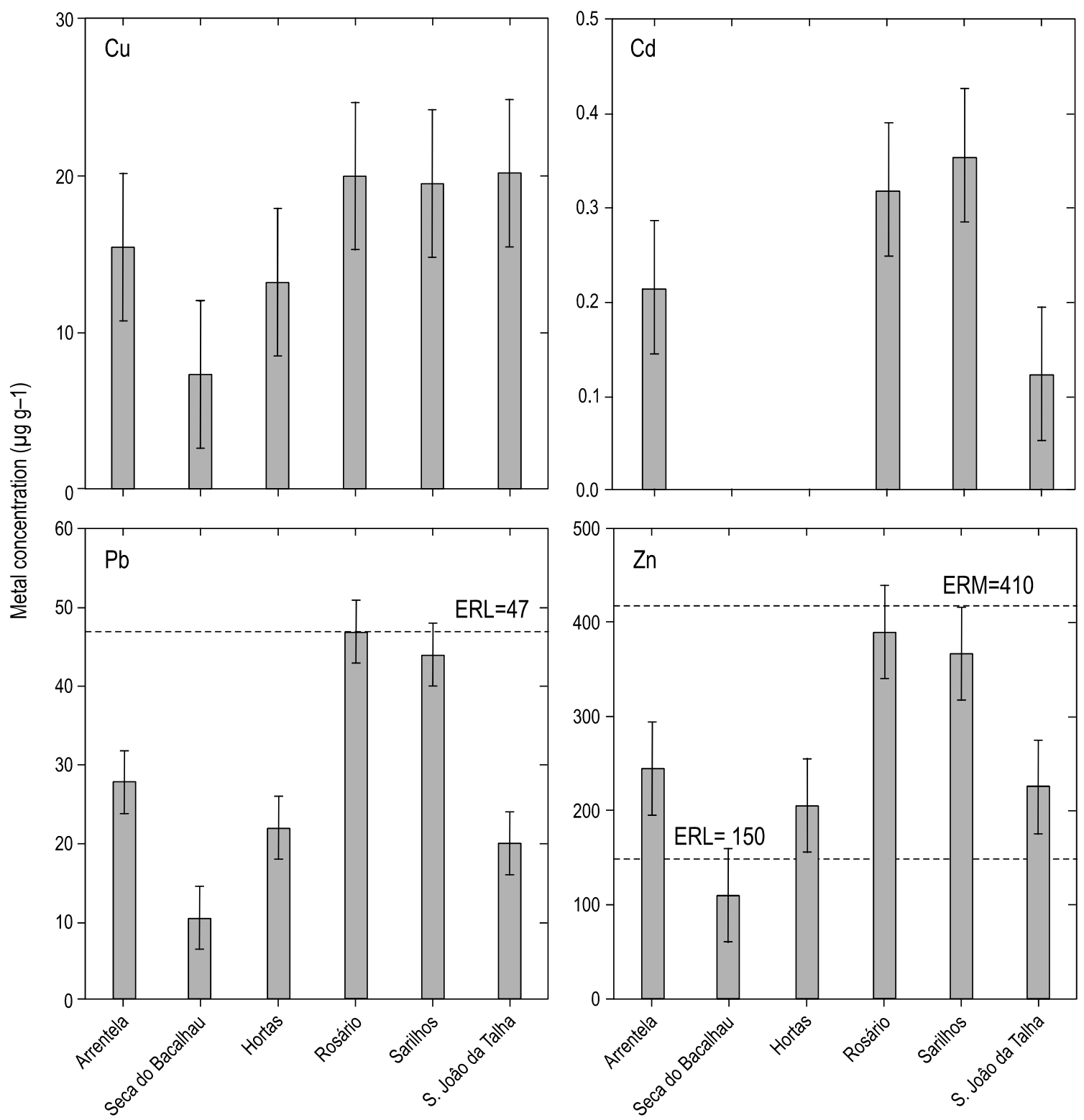

Figure 2. Heavy metal $(\mathrm{Cu}, \mathrm{Cd}, \mathrm{Pb}$, and $\mathrm{Zn}$ ) contents in sediment samples from the six mudflats sampled (standard deviation above bars). Dashed lines represent the effect range low (ERL) and the effect range median (ERM) for each metal.

Figura 2. Contenidos de metales pesados $(\mathrm{Cu}, \mathrm{Cd}, \mathrm{Pb}$ y $\mathrm{Zn})$ en las muestras de sedimento de las seis planicies lodosas estudiadas (desviación estándar arriba de las barras). Las líneas discontinuas representan los niveles bajo y medio del intervalo de efectos (ERL y ERM, respetivamente) de cada metal.

model presented a good fit $\left(R^{2}=0.857\right)$. For this metal, a positive correlation between individuals and sediment contamination levels was observed, with a slope of 0.1369 .

The CCA performed between the diversity and evenness indices, where $94.8 \%$ of the variance was explained by the first axis, revealed that the low diversity areas were those with the higher levels of contamination, organic matter content, and silt and clay proportion (fig. 5). Seca do Bacalhau, the mudflat with lowest heavy metal content in sediments, is clearly isolated from the others. Rosário and Sarilhos, with relatively high levels of $\mathrm{Pb}$ and $\mathrm{Cd}$ contamination and with the lowest degrees of diversity, presented similar positions in the diagram. significativas, excepto para el $\mathrm{Pb}$ en $N$. diversicolor, cuyo modelo de regresión lineal presentó un buen ajuste $\left(R^{2}=\right.$ 0.857). Para este metal se observó una correlación positiva entre los niveles de contaminación en individuos y sedimentos, con una pendiente de 0.1369 .

El CCA realizado entre los índices de diversidad e igualdad, en el que $94.8 \%$ de la varianza fue explicada por el primer eje, indicó que las zonas de baja diversidad fueron las que presentaron los mayores niveles de contaminación, materia orgánica y proporción de limo y arcilla (fig. 5). Seca do Bacalhau, el sitio con menor contenido de metales pesados en los sedimentos, claramente se distingue de los demás. Rosário 

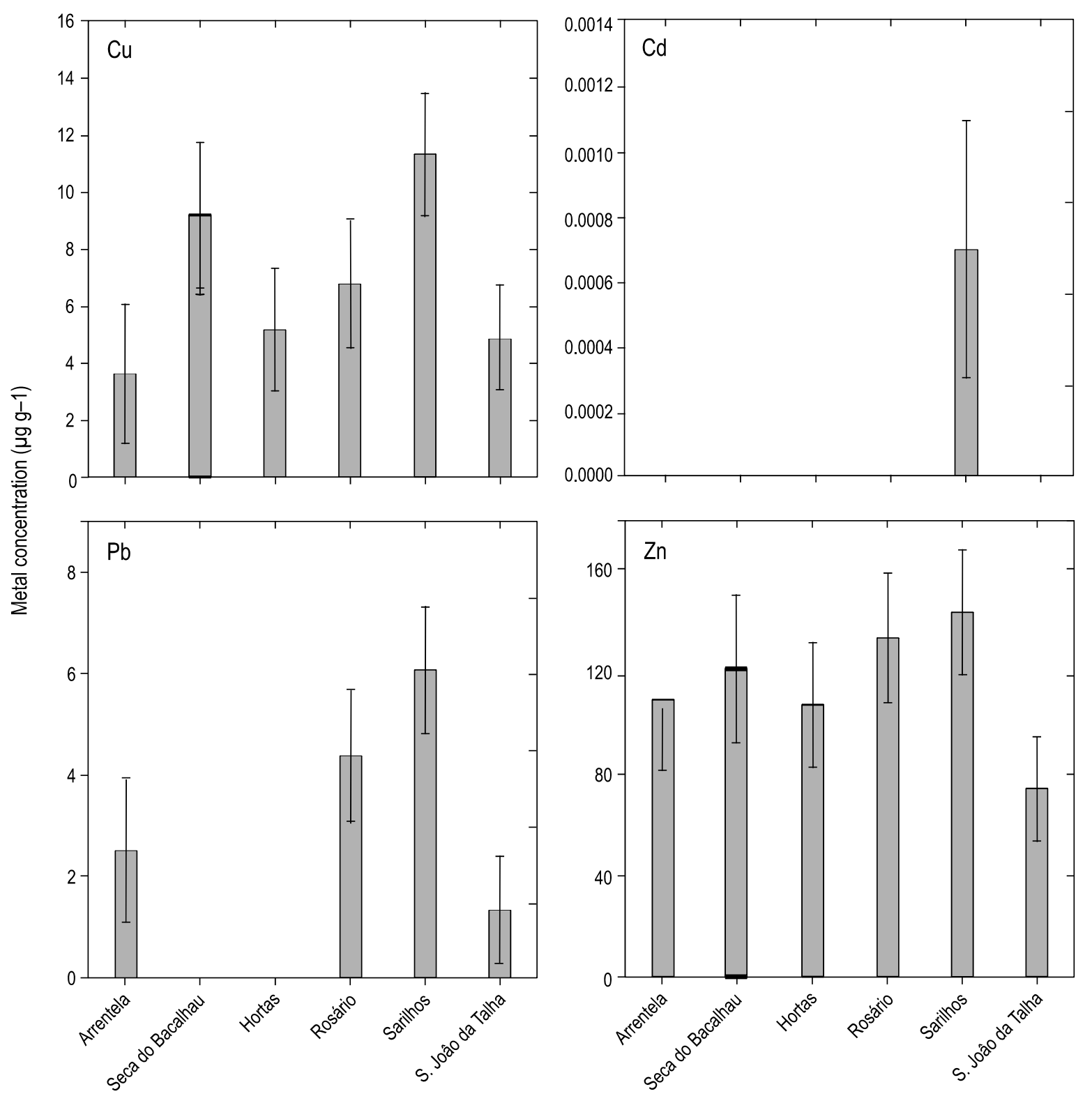

Figure 3. Nereis diversicolor heavy metal $(\mathrm{Cu}, \mathrm{Cd}, \mathrm{Pb}$, and $\mathrm{Zn})$ concentrations at the six mudflats sampled (standard deviation above bars).

Figura 3. Concentración de metales pesados ( $\mathrm{Cu}, \mathrm{Cd}, \mathrm{Pb}$ y $\mathrm{Zn}$ ) en Nereis diversicolor de las seis planicies lodosas muestreadas (desviación estándar arriba de las barras).

Overall, a gradient pattern can be observed since Hortas, Arrentela, and São João da Talha are located at intermediate positions between the diversity and contamination levels.

\section{Discussion}

A low macroinvertebrate community diversity is common in estuarine ecosystems, and the values obtained for the Tagus Estuary mudflats are similar to those reported for other Portuguese estuaries (Mucha and Costa 1999, Mucha et al. 2005). Despite this similarity, the evenness values estimated for the Tagus mudflats were quite low. y Sarilhos, con niveles relativamente altos de contaminación por $\mathrm{Pb}$ y $\mathrm{Cd}$ y con los menores grados de diversidad, ocuparon posiciones similares en el diagrama. En conjunto, se puede observar un patrón de gradiente ya que Hortas, Arrentela y São João da Talha se localizan en posiciones intermedias entre los niveles de contaminación y diversidad.

\section{Discusión}

Es común encontrar una baja diversidad en las comunidades de macroinvertebrados de los ecosistemas estuarinos, y los valores obtenidos para las planicies lodosas del estuario del 

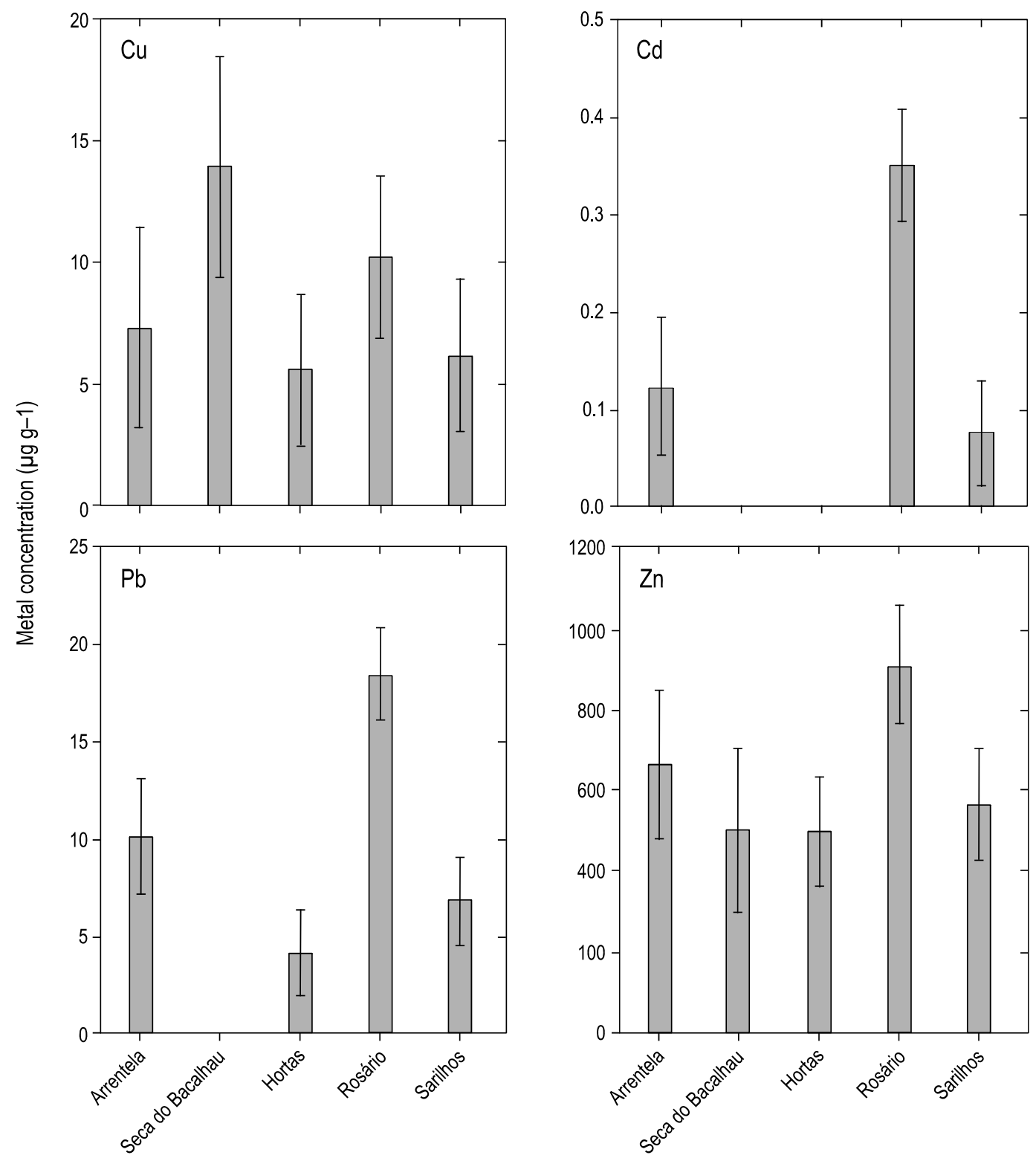

Figure 4. Mean values of Scrobicularia plana heavy metal $(\mathrm{Cu}, \mathrm{Cd}, \mathrm{Pb}$, and $\mathrm{Zn})$ concentrations at the six mudflats sampled (standard deviation above bars).

Figura 4. Valores medios de la concentración de metales pesados ( $\mathrm{Cu}, \mathrm{Cd}, \mathrm{Pb}$ y $\mathrm{Zn}$ ) en Scrobicularia plana de las seis planicies lodosas muestreadas (desviación estándar arriba de las barras).

Species dominance varied according to the sampling area. Although S. plana and $N$. diversicolor are very resistant species (Bryan et al. 1985), they were not equally abundant in all the sampling areas and were scarce at Seca do Bacalhau and São João da Talha, respectively. This may be explained by differences in sediment composition for Seca do Bacalhau and, probably, by the low environmental quality at São João da Talha due to nearby industrial and domestic sewage discharges. In fact, the sediment organic matter content was higher in São João da Talha and Hortas, and the differences between the diversity values of these two mudflats may suggest a higher input of organic pollutants at São João da Talha.
Tajo son similares a los registrados para otros estuarios de Portugal (Mucha y Costa 1999, Mucha et al. 2005). A pesar de esta similitud, los valores de igualdad estimados para las planicies del Tajo resultaron bastante bajos.

La dominancia de especies varió de acuerdo con la zona de muestreo. A pesar de que S. plana y $N$. diversicolor son especies muy resistentes (Bryan et al. 1985), no resultaron ser igualmente abundantes en todos los sitios y fueron escasas en Seca do Bacalhau y São João da Talha, respectivamente. Esto se puede explicar por las diferencias en la composición del sedimento de Seca do Bacalhau y, probablemente, por la baja calidad ambiental de São João da Talha debido a las descargas 
The extremely low abundance or absence of other macrobenthic species, namely crustaceans such as Cyathura carinata, is of high concern given that their absence is an indicator of poor environmental quality (Warwick 2001), and probably reflects the intensity of anthropogenic impacts in the sampling areas. In general, the low diversity and evenness found in the Tagus mudflat macroinvertebrate assemblages was also reflected in the density of benthic organisms. The only exceptions were found at Sarilhos and Rosário, which were heavily contaminated and presented high densities of $N$. diversicolor and S. plana.

Though the sediment metal contents found in the sampling areas considered in this study were lower than those reported by França et al. (2005) in a previous study conducted at Hortas, Rosário and São João da Talha, they were higher than those presented by Vinagre et al. (2008) for saltmarsh areas adjacent to Hortas and Rosário. These differences may be attributed to the spatial and temporal heterogeneity of heavy metal distribution, especially related to the variability introduced by sewage discharges and river inputs, as outlined by other authors (Cheggour et al. 2005, Durou et al. 2005, Mucha et al. 2005, Martínez et al. 2006). Our sampling surveys were performed during July, whereas in the aformentioned studies sampling took place between January and March. The temporal variation of heavy metals in sediments has not been evaluated in these areas of the Tagus Estuary, but for saltmarshes from this estuary, Caçador et al. (2000) reported marked seasonal changes in sediment contamination levels.

The levels of $\mathrm{Cu}$ in our study were one order of magnitude lower that those reported by França et al. (2005). Whether industriales y domésticas cercanas. De hecho, el contenido de materia orgánica del sedimento fue mayor en São João da Talha y Hortas, y las diferencias entre los valores de diversidad de estos dos sitios sugiere una mayor entrada de contaminantes orgánicos en São João da Talha.

La ausencia o extremadamente baja abundancia de otras especies macrobénticas, especialmente crustáceos como Cyathura carinata, es muy preocupante ya que su ausencia indica una pobre calidad ambiental (Warwick 2001), y probablemente refleja la intensidad de los impactos antropogénicos en las zonas de muestreo. En general, la baja diversidad e igualdad encontradas en las comunidades de macroinvertebrados de las planicies lodosas del Tajo también se reflejó en la densidad de los organismos bénticos. Las únicas excepciones se encontraron en Sarilhos y Rosário, los cuales presentaron una fuerte contaminación y altas densidades de $N$. diversicolor y S. plana.

Aunque los contenidos de metales encontrados en los sedimentos de los sitios de muestreo fueron menores que los encontrados por França et al. (2005) en un estudio previo realizado en Hortas, Rosário y São João da Talha, resultaron más altos que los publicados por Vinagre et al. (2008) para zonas de marismas adyacentes a Hortas y Rosário. Estas diferencias pueden atribuirse a la heterogeneidad espacial y temporal de la distribución de metales pesados, especialmente relacionadas con la variabilidad introducida por las descargas de aguas residuales y fluviales, tal y como ha sido mencionado por otros autores (Cheggour et al. 2005, Durou et al. 2005, Mucha et al. 2005, Martínez et al. 2006). Nuestros muestreos se llevaron a cabo en julio, mientras que en los otros estudios los muestreos

Table 3. Biosediment accumulation factor (BSAF) for Nereis diversicolor and Scrobicularia plana in the sampling areas.

Tabla 3. Factor de acumulación biota-sedimento (BSAF) para Nereis diversicolor y Scrobicularia plana en los sitios de muestreo.

\begin{tabular}{|c|c|c|c|c|c|}
\hline & & $\mathrm{Cu}\left(\mu \mathrm{g} \mathrm{g}^{-1}\right)$ & $\mathrm{Cd}\left(\mu \mathrm{g} \mathrm{g}^{-1}\right)$ & $\mathrm{Pb}\left(\mu \mathrm{g} \mathrm{g}^{-1}\right)$ & $\mathrm{Zn}\left(\mu \mathrm{g} \mathrm{g}^{-1}\right)$ \\
\hline \multirow{2}{*}{ Arrentela } & N. diversicolor & 0.2363 & 0.0000 & 0.0899 & 0.4439 \\
\hline & S. plana & 0.4750 & 0.5698 & 0.3649 & 2.6951 \\
\hline \multirow[t]{2}{*}{ Seca do Bacalhau } & N. diversicolor & 1.2585 & - & 0.0761 & 1.1100 \\
\hline & S. plana & 1.9017 & - & 0.2703 & 4.5734 \\
\hline \multirow[t]{2}{*}{ Hortas } & N. diversicolor & 0.3934 & - & 0.0493 & 0.5209 \\
\hline & S. plana & 0.4248 & - & 0.1880 & 2.4316 \\
\hline \multirow[t]{2}{*}{ Rosário } & N. diversicolor & 0.3399 & 0.0000 & 0.0930 & 0.3 .418 \\
\hline & S. plana & 0.4839 & 0.9769 & 0.3556 & 2.1362 \\
\hline \multirow[t]{2}{*}{ Sarilhos } & N. diversicolor & 0.5821 & 0.0020 & 0.1377 & 0.3905 \\
\hline & S. plana & 0.3166 & 0.2125 & 0.1553 & 1.4338 \\
\hline \multirow[t]{2}{*}{ São João da Talha } & N. diversicolor & 0.2432 & 0.0000 & 0.0659 & 0.3290 \\
\hline & S. plana & - & - & - & - \\
\hline \multirow[t]{2}{*}{ Mean BSAF } & N. diversicolor & 0.5089 & 0.0005 & 0.0853 & 0.5227 \\
\hline & S. plana & 0.7204 & 0.5863 & 0.2668 & 2.6741 \\
\hline
\end{tabular}




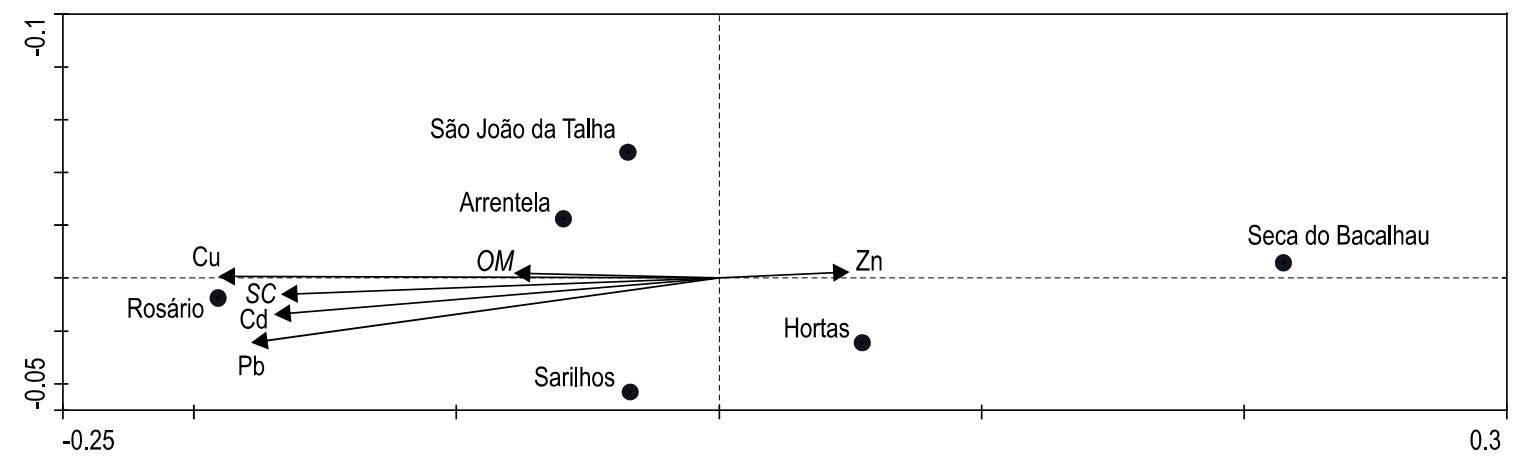

Figure 5. Canonical correspondence analyses between diversity and evenness indices, sediment level of contamination, organic matter content (OM), and silt and clay proportion (SC) at the six sampling sites ( $94.8 \%$ of total variance is explained by the first axis).

Figura 5. Análisis de correspondencia canónica entre los índices de diversidad e igualdad, el nivel de contaminación del sedimento, el contenido de materia orgánica (OM), y la proporción de limo y arcilla (SC) en los seis sitios de muestreo ( $94.8 \%$ de la varianza total es explicada por el primer eje).

these differences are due to temporal variations remains to be seen, but high variations of $\mathrm{Cu}$ contamination in S. plana have been described for areas of sediment deposition (Luoma and Bryan 1982). Seasonal variations have also been reported for $N$. diversicolor, and related to several factors, such as distance to waste disposal sites, salinity variations caused by rainfall, biological characteristics like life cycle phase, among others (Rainbow et al. 1990).

Several authors have outlined that the concentration of heavy metals in sediments is generally the most important variable correlating with metal concentrations in S. plana and N. diversicolor (Luoma and Bryan 1982, Bryan et al. 1985, Amiard et al. 1987). Nevertheless, Luoma and Bryan (1982) suggested that the control on metal availability for S. plana and $N$. diversicolor is different according to metal and species, reflecting multiple processes influencing metal bioavailability in nature. The interaction between metal geochemistry and animal physiology determines the differences in the bioavailability among the toxic metals (Wang 2002, Wang et al. 2002). Therefore, there are interspecific differences in metal concentrations given the different requirements and physiological processes of the different species (Wilson 1994), which may explain the differences in metal concentration between S. plana and $N$. diversicolor.

In the present study, maxima of heavy metal contents in sediment were not coincident with maxima of contamination in the organisms considered. The exception was a good relationship between $\mathrm{Pb}$ concentrations in sediment and $N$. diversicolor. No significant relationships were obtained for S. plana, for which high levels of $\mathrm{Cu}$ were registered compared with the concentration in sediments. This lack of correlation between $\mathrm{Cu}$ concentrations in sediment and in S. plana individuals has been reported by other authors (Wang 2002, Cheggour et al. 2005). Nereis diversicolor has the capacity to regulate $\mathrm{Zn}$ and $\mathrm{Cu}$ concentrations, which are essential metals, to a certain extent (Luoma and Bryan 1982, Amiard et al. 1987, Durou et al. 2005). The results obtained suggest that the levels of contamination of these metals does not exceed the worm's se realizaron entre enero y marzo. No se ha evaluado la variación temporal de metales pesados en los sedimentos de estas zonas del estuario del Tajo, pero para marismas de este mismo estuario Caçador et al. (2000) encontraron claros cambios estacionales en los niveles de contaminación del sedimento.

Los niveles de $\mathrm{Cu}$ en este estudio fueron de un orden de magnitud menor que los obtenidos por França et al. (2005). Está por verse si estas diferencias se deben a variaciones temporales, pero se han descrito variaciones significativas en los niveles de $\mathrm{Cu}$ en S. plana para zonas de depósito de sedimentos (Luoma y Bryan 1982). También se han observado variaciones estacionales en $N$. diversicolor, las cuales se han asociado con varios factores como la distancia a sitios de descarga de residuos, variaciones en la salinidad causadas por la precipitación y características biológicas como la fase del ciclo de vida, entre otros (Rainbow et al. 1990).

Varios autores han mencionado que la concentración de metales pesados en los sedimentos es generalmente la variable más importante que se correlaciona con las concentraciones de metales en S. plana y N. diversicolor (Luoma y Bryan 1982, Bryan et al. 1985, Amiard et al. 1987). No obstante, Luoma y Bryan (1982) indicaron que el control sobre la disponibilidad de metales para S. plana y $N$. diversicolor es diferente según el metal y la especie, lo que refleja que múltiples procesos están influenciando la biodisponibilidad de metales en la naturaleza. La interacción entre la geoquímica de los metales y la fisiología animal determina las diferencias en la biodisponibilidad entre los metales tóxicos (Wang 2002, Wang et al. 2002). Por tanto, existen diferencias interespecíficas en las concentraciones de metales debido a los diferentes requerimientos y procesos fisiológicos de las especies (Wilson 1994), lo cual pudiera explicar las diferencias en la concentración de metales presentadas por S. plana y $N$. diversicolor.

En el presente trabajo, los máximos contenidos de metales pesados en los sedimentos no coincidieron con los valores máximos de contaminación en los organismos estudiados. La excepción fue la buena relación encontrada entre las concentraciones de $\mathrm{Pb}$ en los sedimentos y en $N$. diversicolor. No se 
capacity of regulation (Amiard et al. 1987, Durou et al. 2005). Relationships between concentrations of contaminants in sediments and their bioavailability variation patterns are still poorly understood, but our observations support the fact that several variables control both the bioavailability and accumulation of heavy metals in individuals exposed to contamination (Ansari et al. 2004, Martín-Díaz et al. 2006).

The average BSAF values obtained were similar to those estimated by França et al. (2005) for N. diversicolor and $S$. plana, with a maximum value for $\mathrm{Zn}$ and the highest values associated with S. plana. As described above, we found higher contamination levels in S. plana than in sediment, which can suggest a high rate of accumulation by this species, a physiological mechanism induced by chronic exposure, or even a high relevance of the water column as an additional source of contamination.

Long et al. (1995) calculated sediment ERL (effect range low) and ERM (effect range median) corresponding to the 10th and 50th percentiles, respectively, on an ordered list of concentration in sediment found in the literature that cause any biological effect. These authors outlined that metal concentrations below ERL values may cause minimal toxic effects, that concentrations between ERL and ERM values should be considered to be moderately toxic, leading to occasional effects, and that metal concentrations higher than ERM may have pronounced effects. According to the ERL and ERM values (expressed as $\mu \mathrm{g}^{-1} \mathrm{~g}^{-1}$ dry weight) indicated by Long et al. (1995) for $\mathrm{Cu}(34,270), \mathrm{Cd}(1.2,9.6), \mathrm{Pb}(47,218)$, and $\mathrm{Zn}$ $(150,410)$, the $\mathrm{Pb}$ concentrations in the Rosário sediment and the $\mathrm{Zn}$ values at Arrentela, Seca do Bacalhau, Hortas, and Rosário resgistered in the present study, may have occasional effects on resident organisms. All the other values were below the ERL.

The individuals collected at Sarilhos and Rosário have similar heavy metal concentrations than those reported for invertebrates in heavily contaminated estuaries (Cheggour et al. 2005). The other sites were less contaminated and their heavy metal contents were similar to areas with a low anthropogenic pressure and heavy metal input (Luoma and Bryan 1982). São João da Talha, a site with strong urban runoff and located near industrial sewage discharges, was expected to have higher levels of contamination than those obtained. Several factors, especially water circulation and sediment deposition patterns, may have been responsible for the concentrations found in this study.

Although direct contamination effects on macroinvertebrate assemblages are difficult to assess (Lindegarth and Underwood 2002), several authors have also reported an impoverishment of communities due to heavy metal contamination (e.g., Warwick 2001, Mucha et al. 2005). Compared with other estuaries, namely with UK environments that have been the focus of several ecotoxicology studies, the heavy metal concentrations we obtained for all metals except $\mathrm{Zn}$, which was very high, are similar to those considered moderately contaminated estuaries (Spencer 2002); however, obtuvieron relaciones significativas para S. plana, cuyos niveles de $\mathrm{Cu}$ fueron altos en comparación con las concentraciones en los sedimentos. Esta falta de correlación entre las concentraciones de $\mathrm{Cu}$ en los sedimentos y en los individuos de S. plana ya ha sido mencionada por otros autores (Wang 2002, Cheggour et al. 2005). Nereis diversicolor tiene la capacidad de regular las concentraciones de $\mathrm{Zn}$ y $\mathrm{Cu}$, los cuales son metales esenciales hasta cierto punto (Luoma y Bryan 1982, Amiard et al. 1987, Durou et al. 2005). Los resultados obtenidos sugieren que los niveles de contaminación por estos metales no exceden la capacidad de regulación del poliqueto (Amiard et al. 1987, Durou et al. 2005). Aún no se han entendido bien las relaciones entre las concentraciones de los contaminantes en los sedimentos y los patrones de variación de su biodisponibilidad, pero nuestras observaciones indican que son diversas variables las que controlan tanto la biodisponibilidad como la acumulación de metales pesados en individuos expuestos a la contaminación (Ansari et al. 2004, Martín-Díaz et al. 2006).

Los promedios de BSAF obtenidos fueron similares a los estimados por França et al. (2005) para N. diversicolor y $S$. plana, con un valor máximo para $\mathrm{Zn}$ y los valores más altos asociados con S. plana. Como ya se mencionó, en este estudio se encontraron mayores niveles de contaminación en S. plana que en los sedimentos, lo que puede sugerir una alta tasa de acumulación por tal especie, algún mecanismo fisiológico inducido por la exposición crónica, o hasta una posible importancia de la columna de agua como fuente adicional de contaminación.

Long et al. (1995) calcularon los niveles bajo y medio del intervalo de efectos (ERL y ERM, por sus siglas en inglés) del sedimento, y que corresponden al décimo y quincuagésimo percéntil, respectivamente, en una lista ordenada de las concentraciones en sedimentos, encontradas en la literatura, que causan efectos biológicos. Según estos autores, las concentraciones de metales por debajo de los valores de ERL pueden causar efectos tóxicos mínimos, las concentraciones entre ERL y ERM deberían de considerarse moderadamente tóxicas, causando efectos ocasionales, y las concentraciones por arriba de ERM pueden tener efectos pronunciados. De acuerdo con los valores de ERL y ERM (expresados en $\mu \mathrm{g}^{-1} \mathrm{~g}^{-1}$ de peso seco) indicados por Long et al. (1995) para $\mathrm{Cu}(34,270), \mathrm{Cd}(1.2$, 9.6), $\mathrm{Pb}(47,218)$ y $\mathrm{Zn}(150,410)$, las concentraciones de $\mathrm{Pb}$ en los sedimentos de Rosário y los valores de $\mathrm{Zn}$ registrados en Arrentela, Seca do Bacalhau, Hortas y Rosário en este estudio pueden tener efectos ocasionales sobre los organismos residentes. Todos los demás valores estuvieron por debajo del ERL.

Los individuos recolectados en Sarilhos y Rosário presentaron concentraciones de metales pesados similares a las encontradas en invertebrados de estuarios muy contaminados (Cheggour et al. 2005). Los demás sitios de muestreo resultaron menos contaminados, con contenidos de metales pesados similares a los de áreas con baja presión antropogénica y bajo aporte de metales pesados (Luoma y Bryan 1982). Se esperaba que São João da Talha, un sitio que recibe fuerte descarga 
the level of contamination is similar to the one obtained by Morrisey et al. (2003) for estuaries under strong urban pressure.

The two more contaminated mudflats, Rosário and Sarilhos, were found to have the highest prey availability (highest densities of $N$. diversicolor and S. plana). These two species may be quite resistant to pollutants (Luoma and Bryan 1982, Bryan et al. 1985) and thus may not be extremely affected by metal contamination. However, these levels may have a marked impact on predator species that use these mudflat areas as feeding grounds. In fact, although pre-exposure to contaminations seems to have no effect on some predators, the combined concentrations of heavy metals may affect growth in benthic estuarine fish (Forrester et al. 2003). In addition, the evolution of tolerant populations of prey species may lead not only to changes in the potential for the transfer of heavy metals throughout higher trophic levels in food webs (Rainbow et al. 2004, Wang and Rainbow 2005), but can also be harmful for the integrity of prey species. Regarding the conservation of the Tagus Estuary habitats and their ecological functions, further research should be conducted on these topics, which will be extremely valuable for the development of useful management tools.

\section{Acknowledgements}

The authors would like to thank FCT for partial funding for this project.

\section{References}

Amiard JC, Amiard-Triquet C, Berthet B, Metayer C. 1987. Comparative study of the patterns of bioaccumulation of essential $(\mathrm{Cu}, \mathrm{Zn})$ and non-essential $(\mathrm{Cd}, \mathrm{Pb})$ trace metals in various estuarine and coastal organisms. J. Exp. Mar. Biol. Ecol. 106: 73-89.

Ansari TM, Marr IL, Tariq N. 2004. Heavy metals in marine pollution perspective: A mini review. J. Appl. Sci. 4: 1-20.

Bryan GW, Langston WJ, Hummerston LG, Burt GR. 1985. A guide to the assessment of heavy-metal contamination in estuaries using biological indicators. Marine Biological Association of the United Kingdom, Ocas. Publ. 4, Devon, England, 91 pp.

Cabral HN. 2000. Comparative ecology of sympatric Solea solea and Solea senegalensis, within the nursery areas of the Tagus Estuary, Portugal. J. Fish Biol. 57: 1550-1562.

Caçador I, Vale C, Catarino F. 1993. The effects of plants on the accumulation of $\mathrm{Zn}, \mathrm{Pb}, \mathrm{Cu}$, and $\mathrm{Cd}$ in sediments of the Tagus Estuary salt marshes, Portugal. In: Vernet JP (ed.), Studies in Environmental Sciences, Environment Contamination. Vol. 55. Elsevier Science, Amesterdam, pp. 355-364.

Caçador I, Vale C, Catarino F. 2000. Seasonal variation of $\mathrm{Zn}, \mathrm{Pb}, \mathrm{Cu}$ and $\mathrm{Cd}$ concentration in root-sediment system of Spartina maritima and Halimione portucaloides from Tagus Estuary salt marshes. Mar. Environ. Res. 49: 279-290.

Cheggour M, Chafi AK, Fisher NS, Benbrahim S. 2005. Metal concentrations in sediments and clams in four Maroccan estuaries. Mar. Environ. Res. 59: 119-137.

Durou C, Mouneyrac C, Amiard-Triquet C. 2005. Tolerance to metals and assessment of energy reserves in the polychaete Nereis urbana y está localizado cerca de descargas industriales de aguas residuales, presentara mayores niveles de contaminación que los encontrados. Varios factores, especialmente la circulación del agua y los patrones de depósito sedimentario, pueden haber sido responsables de las concentraciones registradas en este estudio.

A pesar de la dificultad para evaluar los efectos directos de la contaminación en los conjuntos de macroinvertebrados (Lindegarth y Underwood 2002), varios autores también han observado un enpobrecimiento de las comunidades debido a la contaminación por metales pesados (e.g., Warwick 2001, Mucha et al. 2005). Comparadas con las de otros estuarios, especialmente en ambientes del Reino Unido que han sido objeto de varios estudios ecotoxicológicos, las concentraciones de metales pesados obtenidas en este trabajo para todos los metales, con excepción de la del Zn que resultó muy alta, son similares a las de estuarios considerados moderadamente contaminados (Spencer 2002); sin embargo, el nivel de contaminación es similar al obtenido por Morrisey et al. (2003) para estuarios bajo fuerte presión urbana.

Las dos planicies lodosas más contaminadas, Rosário y Sarilhos, presentaron la mayor disponibilidad de presas, esto es, mayores densidades de $N$. diversicolor y S. plana. Estas dos especies pueden ser bastante resistentes a contaminantes (Luoma y Bryan 1982, Bryan et al. 1985) y, por ende, pueden no resultar muy afectadas por la contaminación por metales. No obstante, esta contaminación puede tener un impacto considerable sobre las especies depredadoras que utilizan estas planicies como zonas de alimentación. De hecho, aunque una preexposición a los contaminantes parece no tener ningún efecto sobre los predadores, la concentración combinada de metales pesados puede afectar el crecimiento de los peces bénticos estuarinos (Forrester et al. 2003). Asimismo, la evolución de poblaciones de presas tolerantes puede no sólo causar cambios en el potencial de transferencia de metales pesados a través de los niveles tróficos superiores en las cadenas alimenticias (Rainbow et al. 2004, Wang y Rainbow 2005), sino que también puede ser dañino para la integridad de las especies presas. En cuanto a la conservación de los hábitats del estuario del Tajo y sus funciones ecológicas, se requiere realizar más estudios sobre tales temas, los cuales serán de mucha utilidad para el desarrollo de herramientas de manejo.

\section{Agradecimientos}

Los autores agradecen a la FCT el apoyo financiero parcial para este proyecto.

Traducido al español por Christine Harris.

diversicolor in clean and contaminated estuaries. Environ. Toxicol. 20: 23-31.

Evans PR, Ward RM, Bone M, Leakey M. 1998. Creation of temperate-climate intertidal mudflats: factors affecting 
colonization and use by benthic invertebrates and their bird predators. Mar. Pollut. Bull. 37: 535-545.

Forrester GE, Fredericks BI, Gerdeman D, Evans B, Steele MA, Zayed K, Schweitzer LE, Suffet IH, Vance RR, Ambrose RF. 2003. Growth of estuarine fish is associated with the combined concentration of sediment contaminants and shows no adaptation or acclimation to past conditions. Mar. Environ. Res. 56: 423-442.

França S, Vinagre C, Caçador I, Cabral HN. 2005. Heavy metal concentrations in sediment, benthic invertebrates and fish in three salt marsh areas subjected to different pollution loads in the Tagus Estuary (Portugal). Mar. Pollut. Bull. 50: 993-1018.

Julshamn K, Ringdal O, Slinning KE, Braekkan OR. 1982. Optimization of the determination of selenium in marine samples by atomic absortion spectrometry: Comparison of a flameless graphite furnace atomic absorption system with a hydride generation atomic absorption system. Spectrochim. Acta 37B: 473-482.

Krebs CJ. 1989. Ecological Methodology. Harper Collins, New York, $654 \mathrm{pp}$.

Levin LA, Boesch DF, Covich A, Daham C, Erséus C, Ewel KC, Kneib RT, Moldenke A, Palmer MA, Snelgrove P, Strayer D, Weslawski JM. 2001. The function of marine critical transition zones and the importance of sediment biodiversity. Ecosystems 4: $430-451$.

Lindegarth M, Underwood AJ. 2002. A manipulative experiment to evaluate predicted changes in intertidal, macro-faunal assemblages after contamination by heavy metals. J. Exp. Mar. Biol. Ecol. 274: 41-64.

Long ER, MacDonald DD, Smith SL, Calder FD. 1995. Incidence of adverse biological effects within ranges of chemical concentrations in marine and estuarine sediments. Environ. Manage. 19: 81-97.

Ludwig JA, Reynolds JF. 1988. Statistical Ecology. A primer on methods and computing. John Wiley, New York, 337 pp.

Luoma SN, Bryan GW. 1982. A statistical study of environmental factors controlling concentration of heavy metals in the burrowing bivalve Scrobicularia plana and the polychaete Nereis diversicolor. Estuar. Coast. Shelf Sci. 15: 95-108.

Martín-Díaz ML, Riba I, Casado-Martínez MC, DelValls A. 2006. Bioavailability of metals in sediments from Spanish estuaries using Carcinus maenas. Cienc. Mar. 32: 412-420.

Martínez G, Senior W, Márquez A. 2006. Heavy metal speciation in the surface water dissolved fraction of the low watershed and plume of the Manzanares River, Sucre State, Venezuela. Cienc. Mar. 22: 239-257.

Morrisey DJ, Turner SJ, Mills GN, Williamson RB, Wise BE. 2003. Factors affecting the distribution of benthic macrofauna in estuaries contaminated by urban runoff. Mar. Environ. Res. 55: 113-136.

Mucha AP, Costa MH. 1999. Macrozoobenthic community structure in two Portuguese estuaries: Relationship with organic enrichment and nutrient gradients. Acta Oecol. 20: 363-376.
Mucha AP, Vasconcelos MTSD, Bordalo AA. 2005. Spatial and seasonal variations of the macrobenthic community and metal contamination in the Douro Estuary (Portugal). Mar. Environ. Res. 60: 531-550.

Otte ML. 1991. Heavy metals and arsenic in vegetation of salt marshes and floodplains. Ph.D. thesis, Vrije University, Amsterdam, Netherlands, $188 \mathrm{pp}$.

Preston BJ. 2002. Indirect effects in aquatic ecotoxicology: Implications for ecological risk assessment. Environ. Manage. 29: 311-323.

Rainbow PS, Phillips DJ, Depledge MH. 1990. The significance of trace metal concentration in marine invertebrates. Mar. Pollut. Bull. 21: 321-324.

Rainbow PS, Amiard-Triquet C, Amiard JC, Smith BD, Best SL, Nassiri Y, Langston WJ. 1999. Trace metal uptake rates in crustaceans (amphipods and crabs) from coastal sites in New Europe differentially enriched with metals. Mar. Ecol. Prog. Ser. 183: 189-203.

Rainbow PS, Geffard A, Jeantet AY, Smith BD, Amiard JC, AmiardTriquet C. 2004. Enhanced food-chain transfer of copper from a diet of copper-tolerant estuarine worms. Mar. Ecol. Prog. Ser. 271: 183-191.

Saiz-Salinas JI, Ruiz JM, Frances-Zubillaga G. 1996. Heavy metal levels in intertidal sediments and biota from the Bidasoa Estuary. Mar. Pollut. Bull. 32: 69-71.

Spencer KL. 2002. Spatial variability of metals in the inter-tidal sediments of Medway Estuary, Kent, UK. Mar. Pollut. Bull. 44: 933-944.

Szefer P, Ali AA, Ba-Haroon AA, Rajeh AA, Gedon J, Nabrzyski M. 1999. Distribution and relationships of selected trace metals in molluscs and associated sediments from the Gulf of Aden, Yemen. Environ. Pollut. 106: 299-314.

Usero J, Morillo J, Gracia I. 2005. Heavy metal concentration in molluscs from the Atlantic coast of southern Spain. Chemosphere 59: 1175-1181.

Vinagre C, Cabral HN, Caçador I. 2008. Influence of halophytes and metal contamination on salt-marsh macrobenthic communities. Estuar. Coast. Shelf Sci. 76: 715-722.

Wang WX. 2002. Interactions of trace metals and different marine food chains. Mar. Ecol. Prog. Ser. 243: 295-309.

Wang WX, Rainbow PS. 2005. Influence of metal exposure history on trace metal uptake and accumulation by marine invertebrates. Ecotoxicol. Environ. Saf. 61: 145-159.

Wang WX, Yan QL, Fan W, Xu Y. 2002. Bioavailability of sedimentary metals from a contaminated bay. Mar. Ecol. Prog. Ser. 240: 23-38.

Warwick RM. 2001. Evidence for the effect of metal contamination on the intertidal macrobenthic assemblages of Fal Estuary. Mar. Pollut. Bull. 42: 145-148.

Wilson JG. 1994. The role of bioindicators in estuarine management. Estuaries 17: 94-101.

Recibido en febrero de 2008; aceptado en julio de 2008. 